\title{
Food and Feeding Ecology of Mugil cephalus from Krishnapatnam and Mypadu Coasts of Nellore District, Andhra Pradesh, India
}

\author{
D. Lavanya ${ }^{1 *}$, D. Ramalingaiah ${ }^{1}$, T. Suguna ${ }^{2}$, \\ D. Raveendra Kumar Reddy ${ }^{3}$ and K. Madhavi ${ }^{4}$ \\ ${ }^{1}$ Department of Fisheries Resource Management, College of Fishery Science, Sri \\ Venkateswara Veterinary University, Muthukur - 524 344, (A.P.), India \\ ${ }^{2}$ Department of Fisheries Resource Management, Fisheries Research Station, \\ $S V V U$, Undi, Bhimavaram (A.P.), India \\ ${ }^{3}$ Department of Aquaculture, College of Fishery Science, \\ SVVU, Muthukur - 524344 (A.P.), India \\ ${ }^{4}$ Department of Aquatic Environment Management, College of Fishery Science, SVVU, \\ Muthukur - 524344 (A.P.), India \\ *Corresponding author
}

\begin{tabular}{|c|c|}
\hline & A B S T R A C T \\
\hline & \multirow{6}{*}{$\begin{array}{l}\text { The flathead grey mullet, Mugil cephalus, is a mullet of the genus Mugil in the family } \\
\text { Mugilidae, Kingdom: Animalia; Class: Actinopterygii; and Order: Mugiliformes; is a } \\
\text { brackish water fish also can thrive well in fresh water and marine waters. Study on the } \\
\text { food and feeding habits of Mugil cephalus was conducted between April, } 2016 \text { to March, } \\
2017 \text { at monthly intervals from Krishnapatnam and Mypadu coasts of Nellore District, } \\
\text { Andhra Pradesh. Observation of feeding habits indicated flathead grey mullet as } \\
\text { omnivorous feeder. Although sand and mud comprises highest amount (35.52\% from } \\
\text { Krishnapatnam and } 37.953 \% \text { from Mypadu coast), diatoms and algal matter forms the } \\
\text { basic food of the fish. High feeding intensity in M. cephalus was observed during May, } \\
2016 \text { and March, } 2017 \text { in Krishnapatnam and Mypadu coasts respectively. Maximum } \\
\text { number of empty stomachs observed during February, } 2017 \text { and December, } 2016 \text { from } \\
\text { Krishnapatnam and Mypadu coasts respectively. The values of gastro-somatic index in the } \\
\text { present study ranged } 1.56-4.15 \text { (males - } 1.72 \text { to } 3.08 \text {; females - } 1.56 \text { to } 4.15 \text { ) from } \\
\text { Krishnapatnam coast and } 1.99-3.89 \text { (males - } 1.99 \text { to } 3.14 \text {; females - } 2.02 \text { to } 3.89 \text { ) from } \\
\text { Mypadu coast. }\end{array}$} \\
\hline Keywords & \\
\hline $\begin{array}{l}\text { Mugil cephalus, Food } \\
\text { composition, Feeding } \\
\text { intensity, Gastro } \\
\text { somatic Index }\end{array}$ & \\
\hline Article Info & \\
\hline $\begin{array}{l}\text { Accepted: } \\
20 \text { March } 2 \\
\text { Available C } \\
10 \text { April } 20\end{array}$ & \\
\hline & \\
\hline
\end{tabular}

\section{Introduction}

Grey mullets contribute significantly to the fishery of tropical and subtropical regions of the world (Wijeyaratne and Costa, 1986; Koutrakis et al., 1994). Subsequently, they are a major source of protein requirements of the peoples of many countries (ICLARM, 1980). Food is the basic source of energy required to perform the physiological activities such as growth and reproduction for survival and to maintain homeostasis. Fishes acquire food 
from the surrounding aquatic environment and are highly adopted in their food and feeding habits, utilizing most of the readily available food. The different feeding habits of adults and juveniles of the grey mullet make them not competitive for food in an ecosystem.

Mullets comprise one of the most important fisheries in coastal waters of India. The flathead grey mullet is one of the common mullet found along the coasts of Mypadu and Krishnapatnam (Kp) in Nellore District and provides livelihood for the local fishermen. However information on the feeding habits of grey mullet from these coasts is not available, present study deals with the food and feeding habits.

\section{Materials and Methods}

A total of 720 specimen of Mugil cephalus were collected from Krishnapatnam (Kp) $\left(14.29^{0} \mathrm{~N}, 80.12{ }^{0} \mathrm{E}\right)$ and Mypadu $\left(14.51^{0} \mathrm{~N}\right.$, $80.17^{0}$ E) Coasts of Nellore district, Andhra Pradesh, randomly from April, 2016 to March, 2017 at monthly intervals. Data was collected from fishermen and several visits were made to these areas during the study period to collect accurate information regarding mullet fisheries. Based on the fish catch, species richness and fish abundance data was generated for each site respectively. Mugil cephalus comprised the total length ranging from 115 - $320 \mathrm{~mm}$ with the weight ranging from $10-320 \mathrm{~g}$ from Kp coast and at Mypadu Coast the total length ranging from 120 - 360 $\mathrm{mm}$ with the weight ranging from $12-340 \mathrm{~g}$ from Mypadu Coast. Fishes were observed for total length, total weight, gut weight, feeding intensity and stomach contents.

\section{Gastro-somatic Index (GaSI)}

Specimens were dissected ventrally and noted the condition of stomach with reference to the distension sex and stage of maturity of the specimen recorded. Volume of the stomach was determined by displacement method and the Gastro Somatic Index (GSI) was calculated by the formula.

$$
\text { GaSI }=\frac{\text { Weight of the stomach }}{\text { Total weight of the fish }}
$$

The stomach contents were emptied in a clean Petri-dish and different types of food items present in it were identified. The percentage occurrences of the different food items were visually estimated, under electron microscope.

\section{Feeding intensity}

By eye estimation, stomach were allotted certain points such as gorged, full stomach, 3/4 full, $1 / 2$ full, $1 / 4$ full, trace and empty. Fishes with gorged and full stomach were considered as actively fed, $3 / 4$ and $1 / 2$ as moderately fed, $1 / 4$ and trace as poorly fed as adapted by Nair (1980).

\section{Index of preponderence}

The index of preponderance adopted here is expressed as:

$$
\mathrm{Ii}=\frac{\% \mathrm{Vi} \text { x \%Oi }}{\sum(\% \mathrm{Vi} \text { x \%Oi })}
$$

Where, $\mathrm{Vi}$ and $\mathrm{Oi}$ are the volume and occurrence index respectively of food items presented in percentage. For the examination of occurrence, total number of occurrence of all the items were scaled down to give the percentage composition of the diet i.e. if food I occurs $\mathrm{Ni}$ times then percentage of occurrence of food i may be given as

$$
\% \mathrm{Oi}=\frac{\mathrm{Ni}}{\sum \mathrm{Ni}}
$$


Where $\% \mathrm{Oi}=$ percentage occurrence of food

Attempts were made to identify the food item upto species level wherever possible.

\section{Results and Discussion \\ Index of preponderence}

Among the various types of food items found in the mullet stomach, Sand and mud accounted high in the mullet stomach shows the benthic feeding habit of the fish with $32.52 \%$ from $\mathrm{Kp}$ and $37.95 \%$ from Mypadu coasts.

Diatoms were the major food items comprising $34.1775 \%$ from $\mathrm{Kp}$ coast and $30.8167 \%$ from Mypadu coast followed by decayed organic matter $(20.035 \%$ from $\mathrm{Kp}$ and 19.0592 from Mypadu coast).

\section{Composition of food items}

The different types of food items found in the stomach of mullet show the euryphagic/ omnivorous feeding habit. Various categories of food items observed in the mullet gut are diatoms, algae, molluscans, decayed organic matter, sand \& mud and miscellaneous matter included insects, fish scales, eggs, etc. The species of diatoms observed in the gut contents of $M$. cephalus were Cyclotella sp., Gyrosigma sp., Fragilaria sp., Nitzschia sp. Pinnularia sp. and Navicula sp.

The algal species observed in the gut contents of M.cephalus were Spirogyra sp., Chlorella sp. and Chaetophora sp. belongs to Chlorophyceae; Spirulina sp. and Oscillatoria sp. belongs to Myxophyceae. Miscellaneous matter included the insects, fish scales, eggs, etc. Month-wise percentage composition of gut contents in $M$. cephalus from both the coasts was presented in the tables 1 and 2 (Fig. 1 and 2).

\section{Feeding intensity in relation to month}

Feeding intensity in relation to month in M.cephalus from Kp coast

In the present investigation, on an average, $13.73 \%$ of fishes examined were highly fed, $38.52 \%$ moderately fed, $38.11 \%$ low fed and $9.63 \%$ empty from Kp coast (Table 3). Moderate type of feeding intensity was observed low in the month of December (15.55\%). Maximum percent of empty stomachs were observed in February (13.73\%). Maximum percentage of moderately fed stomachs were encountered during July $(56.41 \%)$ followed by June (52.77\%) (Fig. 3).

\section{Feeding intensity in relation to month in M.cephalus from Mypadu coast}

In the present investigation, on an average, $14.29 \%$ of the fishes examined were highly fed, $41.67 \%$ moderately fed, $36.11 \%$ low fed and $7.95 \%$ empty (Table 4). Maximum percent of moderately fed stomachs were encountered during August (46.66\%) followed by July $(43.59 \%)$.

Maximum percent of highly fed stomachs were encountered in March $(21.06 \%)$ and empty stomachs in the month of December (12.24\%) (Fig. 4).

\section{Gastro somatic index (GaSI)}

\section{Month-wise GaSI of M.cephalus from Kp coast}

The values of GaSI (male and Female) is presented in Table 5. The highest GaSI values in males were estimated for the month of July (3.08) followed by February, 2017 (2.96) and June, 2016 (2.73) and the lowest value was estimated during August (1.72) followed by November (2.05) (Fig. 5). 
Int.J.Curr.Microbiol.App.Sci (2018) 7(4): 2616-2630

Table.1 Month-wise percentage composition of gut contents in M. cephalus from Kp coast

\begin{tabular}{|l|l|l|l|l|l|l|l|}
\hline Month & Diatoms & Algae & Mollusks & Detritus & $\begin{array}{l}\text { Sand } \\
\text { and mud }\end{array}$ & $\begin{array}{l}\text { Misc. food } \\
\text { items }\end{array}$ & $\begin{array}{l}\text { Unidentified } \\
\text { food mass }\end{array}$ \\
\hline A pril,2016 & 39.82 & 10.26 & 0.24 & 12.88 & 34.27 & 0.12 & 2.41 \\
\hline May & 36.52 & 7.62 & 0.86 & 20.00 & 31.24 & 0.54 & 3.22 \\
\hline June & 23.26 & 9.11 & 0.57 & 23.97 & 39.48 & 0.60 & 3.01 \\
\hline July & 24.96 & 12.48 & 0.95 & 20.67 & 39.32 & 0.48 & 1.14 \\
\hline Aug & 48.46 & 13.06 & 0.72 & 18.06 & 17.12 & 0.51 & 2.07 \\
\hline Sept & 32.48 & 11.67 & 0.63 & 12.89 & 39.19 & 0.33 & 2.81 \\
\hline Oct & 39.62 & 10.48 & 0.20 & 26.74 & 21.28 & 0.43 & 1.25 \\
\hline Nov & 28.87 & 9.67 & 0.36 & 31.48 & 26.54 & 0.82 & 2.26 \\
\hline Dec & 29.38 & 9.82 & 0.59 & 19.56 & 37.97 & 0.76 & 1.92 \\
\hline Jan,2017 & 31.87 & 10.16 & 0.44 & 21.40 & 34.40 & 0.51 & 1.22 \\
\hline Feb & 33.41 & 9.81 & 0.37 & 19.51 & 35.39 & 0.42 & 1.09 \\
\hline March & 41.48 & 8.72 & 0.41 & 13.26 & 34.04 & 0.27 & 1.82
\end{tabular}

Table.2 Month-wise percentage composition of gut contents in M. cephalus from Mypadu coast

\begin{tabular}{|c|c|c|c|c|c|c|c|}
\hline Month & Diatoms & Algae & Molluses & Detritus & $\begin{array}{c}\text { Sand \& } \\
\text { mud }\end{array}$ & $\begin{array}{c}\text { Misc. food } \\
\text { items }\end{array}$ & $\begin{array}{c}\text { Unidentified } \\
\text { food mass }\end{array}$ \\
\hline April, 2016 & 35.27 & 9.96 & 0.29 & 13.06 & 38.50 & 0.34 & 2.58 \\
\hline May & 38.48 & 10.04 & 0.38 & 19.87 & 27.36 & 0.27 & 3.60 \\
\hline June & 34.24 & 8.96 & 0.35 & 18.68 & 35.04 & 0.42 & 2.31 \\
\hline July & 29.51 & 11.42 & 0.52 & 20.00 & 36.15 & 0.51 & 1.89 \\
\hline Aug & 26.47 & 9.48 & 0.32 & 19.43 & 42.42 & 0.23 & 1.65 \\
\hline Sept & 31.01 & 8.36 & 0.43 & 17.68 & 40.35 & 0.33 & 1.84 \\
\hline Oct & 26.67 & 8.28 & 0.35 & 18.04 & 44.72 & 0.29 & 1.65 \\
\hline Nov & 24.88 & 7.32 & 0.66 & 24.20 & 41.11 & 0.34 & 1.49 \\
\hline Dec & 27.32 & 8.91 & 0.36 & 21.60 & 40.16 & 0.38 & 1.27 \\
\hline Jan, 2017 & 29.48 & 9.01 & 0.42 & 20.72 & 38.54 & 0.27 & 1.56 \\
\hline Feb & 31.69 & 10.22 & 0.37 & 19.80 & 35.81 & 0.39 & 1.72 \\
\hline March & 34.78 & 11.63 & 0.26 & 15.63 & 35.27 & 0.42 & 2.01 \\
\hline
\end{tabular}


Table.3 Month-wise percentage of feeding intensity in M.cephalus from Kp coast

\begin{tabular}{|c|c|c|c|c|c|c|c|c|}
\hline \multirow[t]{2}{*}{ Month } & \multirow[t]{2}{*}{$\begin{array}{c}\text { No. of } \\
\text { Specimen }\end{array}$} & \multicolumn{2}{|c|}{ High feeding } & \multicolumn{2}{|c|}{$\begin{array}{l}\text { Moderate } \\
\text { feeding }\end{array}$} & \multicolumn{2}{|c|}{ Low feeding } & \multirow[t]{2}{*}{ Empty } \\
\hline & & Gorged & Full & $3 / 4^{\text {th }}$ & $1 / 2$ full & $1 / 4^{\text {th }}$ full & Trace & \\
\hline April,2016 & 32 & - & 18.75 & 15.63 & 25.00 & 18.75 & 12.50 & 9.37 \\
\hline May & 31 & - & 19.35 & 12.90 & 25.82 & 19.35 & 12.90 & 9.68 \\
\hline June & 36 & - & 16.67 & 22.22 & 30.55 & 16.67 & 13.89 & - \\
\hline July & 39 & - & 17.95 & 25.64 & 30.77 & 15.38 & 10.26 & - \\
\hline Aug & 42 & - & 11.90 & 14.29 & 19.05 & 26.19 & 16.67 & 11.90 \\
\hline Sept & 40 & - & 15.00 & 12.50 & 20.00 & 25.00 & 17.50 & 10.00 \\
\hline Oct & 38 & - & 13.16 & 21.06 & 28.95 & 18.42 & 10.53 & 7.88 \\
\hline Nov & 44 & - & 11.36 & 13.65 & 18.18 & 27.27 & 18.18 & 11.36 \\
\hline Dec & 45 & - & 13.33 & 13.33 & 17.78 & 26.67 & 15.56 & 13.33 \\
\hline Jan, 2017 & 49 & - & 10.20 & 14.29 & 18.37 & 26.53 & 18.37 & 12.24 \\
\hline Feb & 51 & - & 9.80 & 13.72 & 21.57 & 25.49 & 15.69 & 13.73 \\
\hline March & 41 & - & 12.20 & 14.63 & 19.51 & 24.39 & 17.07 & 12.20 \\
\hline
\end{tabular}

Table.4 Month-wise percentage of feeding intensity in $M$. cephalus from Mypadu coast

\begin{tabular}{|c|c|c|c|c|c|c|c|c|}
\hline \multirow{2}{*}{ Month } & \multirow[t]{2}{*}{$\begin{array}{c}\text { No. of } \\
\text { Specimen }\end{array}$} & \multicolumn{2}{|c|}{ High feeding } & \multicolumn{2}{|c|}{$\begin{array}{l}\text { Moderate } \\
\text { feeding }\end{array}$} & \multicolumn{2}{|c|}{ Low feeding } & \multirow[t]{2}{*}{ Empty } \\
\hline & & Gorged & Full & $3 / 4^{\text {th }}$ & $1 / 2$ full & $1 / 4^{\text {th }}$ & Trace & \\
\hline April,2016 & 37 & - & 13.51 & 16.22 & 24.32 & 21.62 & 16.22 & 8.11 \\
\hline May & 32 & - & 12.50 & 15.63 & 25.00 & 21.87 & 15.63 & 9.37 \\
\hline June & 41 & - & 17.07 & 19.51 & 24.40 & 21.95 & 17.07 & - \\
\hline July & 39 & - & 12.82 & 20.51 & 23.08 & 17.95 & 17.95 & 7.69 \\
\hline$\overline{\text { Aug }}$ & 45 & - & 15.56 & 24.44 & 22.22 & 20.00 & 11.11 & 6.67 \\
\hline Sept & 47 & - & 14.89 & 19.15 & 23.40 & 21.28 & 12.77 & 8.51 \\
\hline Oct & 36 & - & 11.11 & 16.67 & 25.00 & 22.22 & 16.67 & 8.33 \\
\hline Nov & 50 & - & 14.00 & 18.00 & 22.00 & 20.00 & 14.00 & 12.00 \\
\hline Dec & 49 & - & 12.24 & 18.37 & 20.41 & 22.45 & 14.29 & 12.24 \\
\hline Jan,2017 & 43 & - & 13.95 & 20.93 & 18.60 & 25.58 & 11.63 & 9.31 \\
\hline Feb & 47 & - & 12.77 & 21.28 & 21.28 & 19.14 & 14.90 & 10.65 \\
\hline March & 38 & - & 21.06 & 15.79 & 23.68 & 23.68 & 15.79 & - \\
\hline
\end{tabular}


Table.5 Month-wise gastro-somatic index of M.cephalus from Kp coast

\begin{tabular}{|c|c|c|c|c|}
\hline \multirow{2}{*}{ Month } & No. of male & No. of female & \multicolumn{2}{|c|}{ Gastro-somatic index (GaSI) } \\
\hline & & & Male & Female \\
\hline April, 2016 & 21 & 16 & 2.32 & 2.45 \\
\hline May & 22 & 14 & 2.61 & 3.62 \\
\hline June & 21 & 14 & 2.73 & 4.13 \\
\hline July & 28 & 14 & 3.00 & 4.15 \\
\hline Aug & 24 & 15 & 1.72 & 1.63 \\
\hline Sept & 23 & 21 & 2.46 & 3.20 \\
\hline Oct & 22 & 18 & 2.63 & 2.57 \\
\hline Nov & 27 & 23 & 2.05 & 2.26 \\
\hline Dec & 20 & 18 & 2.19 & 2.09 \\
\hline Jan, 2017 & 24 & 19 & 2.30 & 2.28 \\
\hline Feb & 24 & 16 & 2.96 & 2.80 \\
\hline March & 21 & 17 & 2.71 & 3.33 \\
\hline
\end{tabular}

Table.6 Month-wise gastro-somatic index of M. cephalus from Mypadu coast

\begin{tabular}{|c|c|c|c|c|}
\hline Month & No. of male & No. of female & \multicolumn{2}{|c|}{ Gastro-somatic index (GaSI) } \\
\hline & & & Male & Female \\
\hline April,2016 & 22 & 13 & 2.52 & 2.91 \\
\hline May & 23 & 12 & 2.30 & 3.26 \\
\hline June & 20 & 20 & 2.48 & 3.89 \\
\hline July & 23 & 18 & 3.14 & 3.82 \\
\hline Aug & 23 & 21 & 1.99 & 2.02 \\
\hline Sept & 25 & 26 & 2.21 & 3.11 \\
\hline Oct & 26 & 18 & 2.06 & 2.51 \\
\hline Nov & 20 & 19 & 2.25 & 2.46 \\
\hline Dec & 21 & 17 & 2.61 & 2.54 \\
\hline Jan,2017 & 24 & 16 & 2.78 & 2.09 \\
\hline Feb & 22 & 14 & 2.61 & 2.59 \\
\hline March & 21 & 13 & 2.86 & 3.58 \\
\hline
\end{tabular}


Fig.1 Composition of food items in M. cephalus from Kp coast

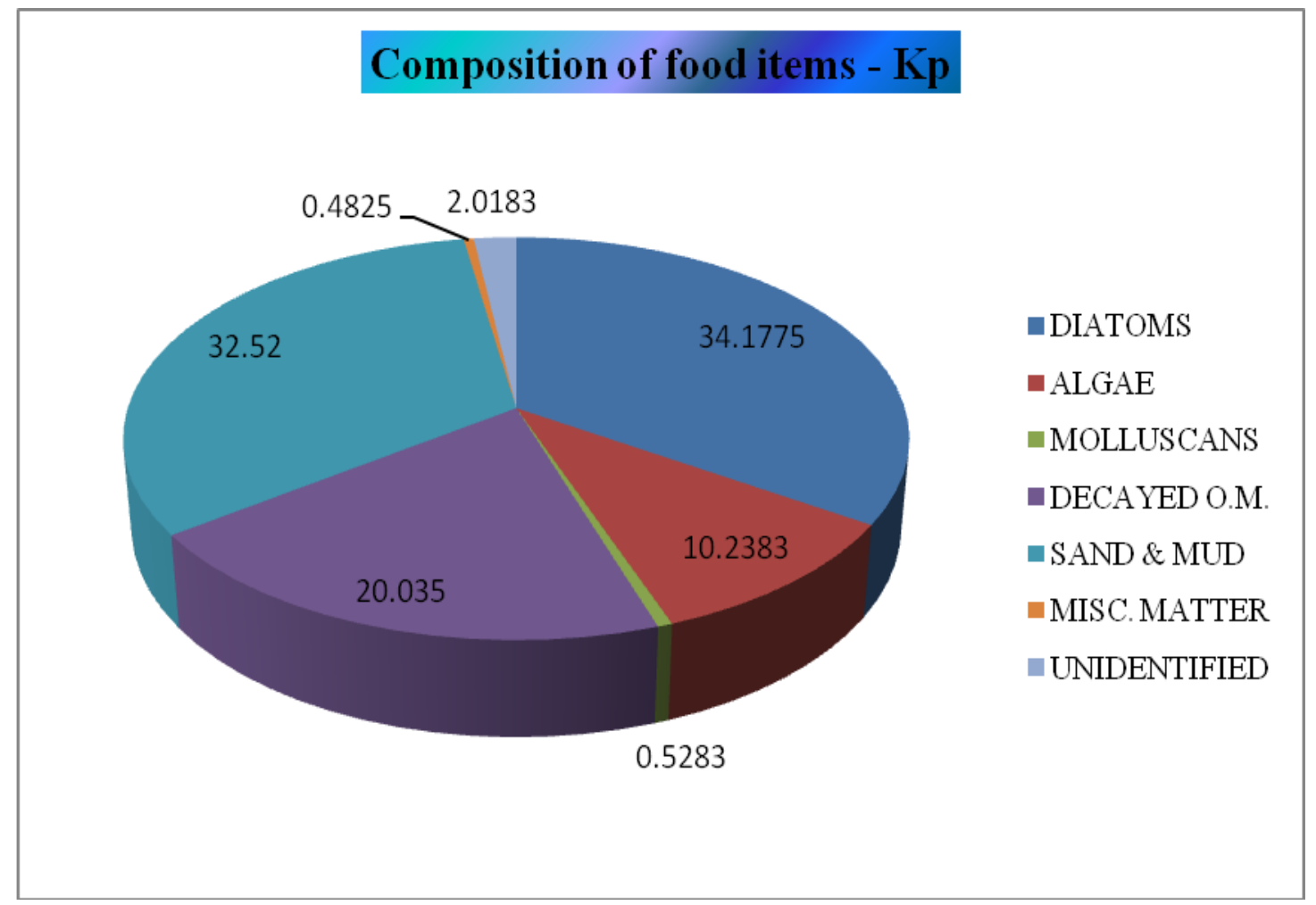

Fig.2 Composition of gut contents in M. cephalus from Mypadu coast

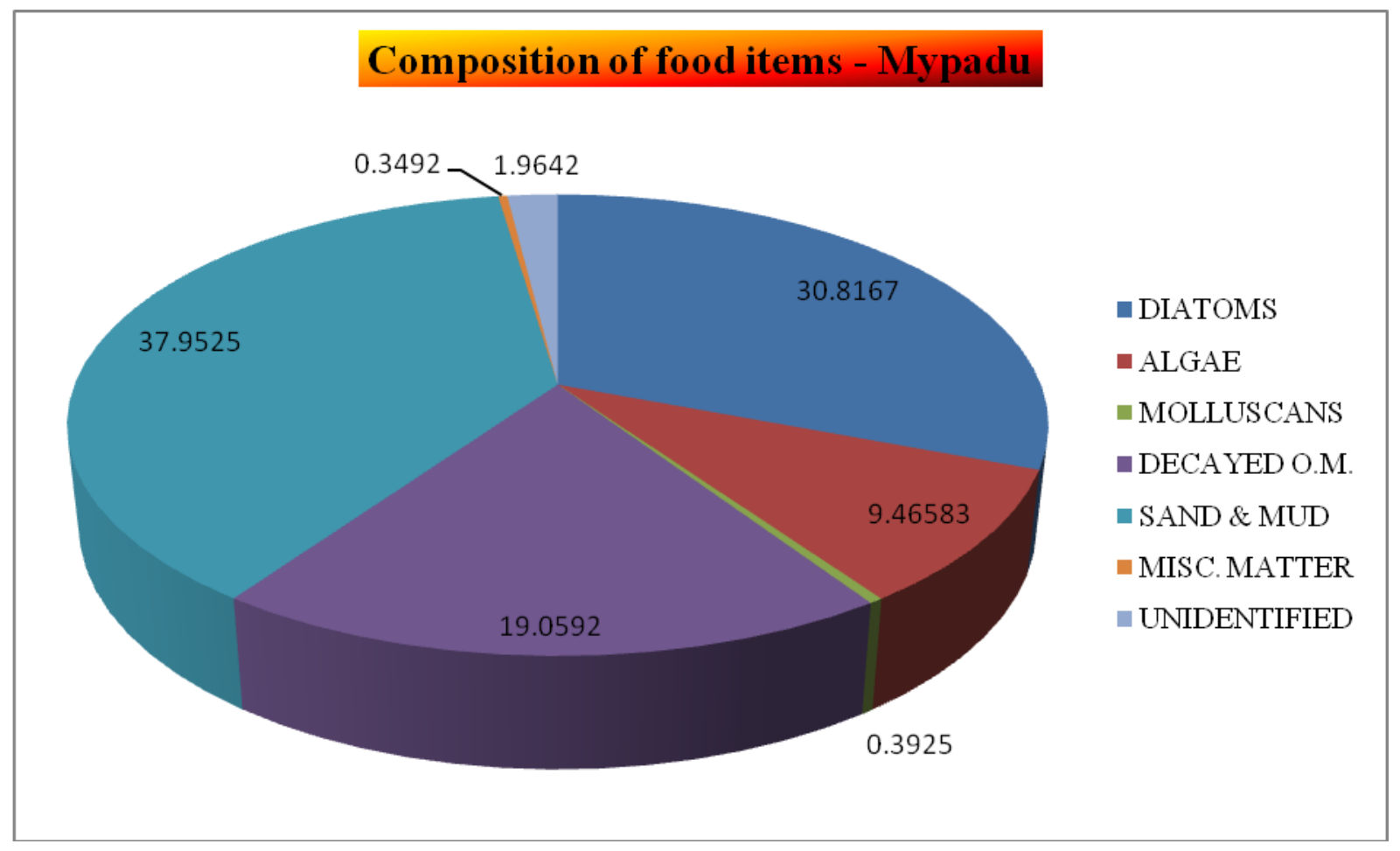


Fig.3 Month-wise feeding intensity of $M$. cephalus from Kp coast

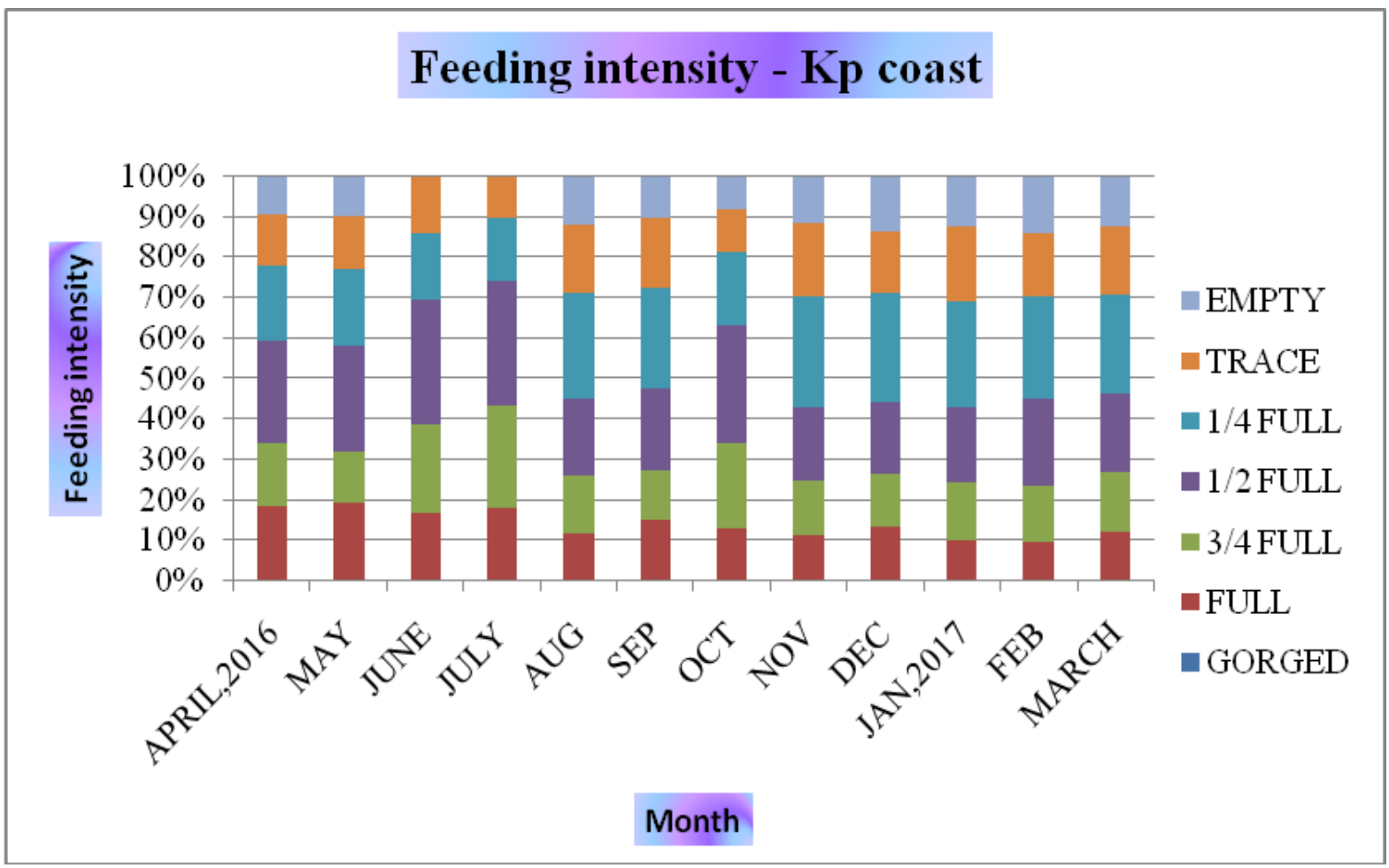

Fig.4 Month-wise feeding intensity of M. cephalus from Mypadu coast

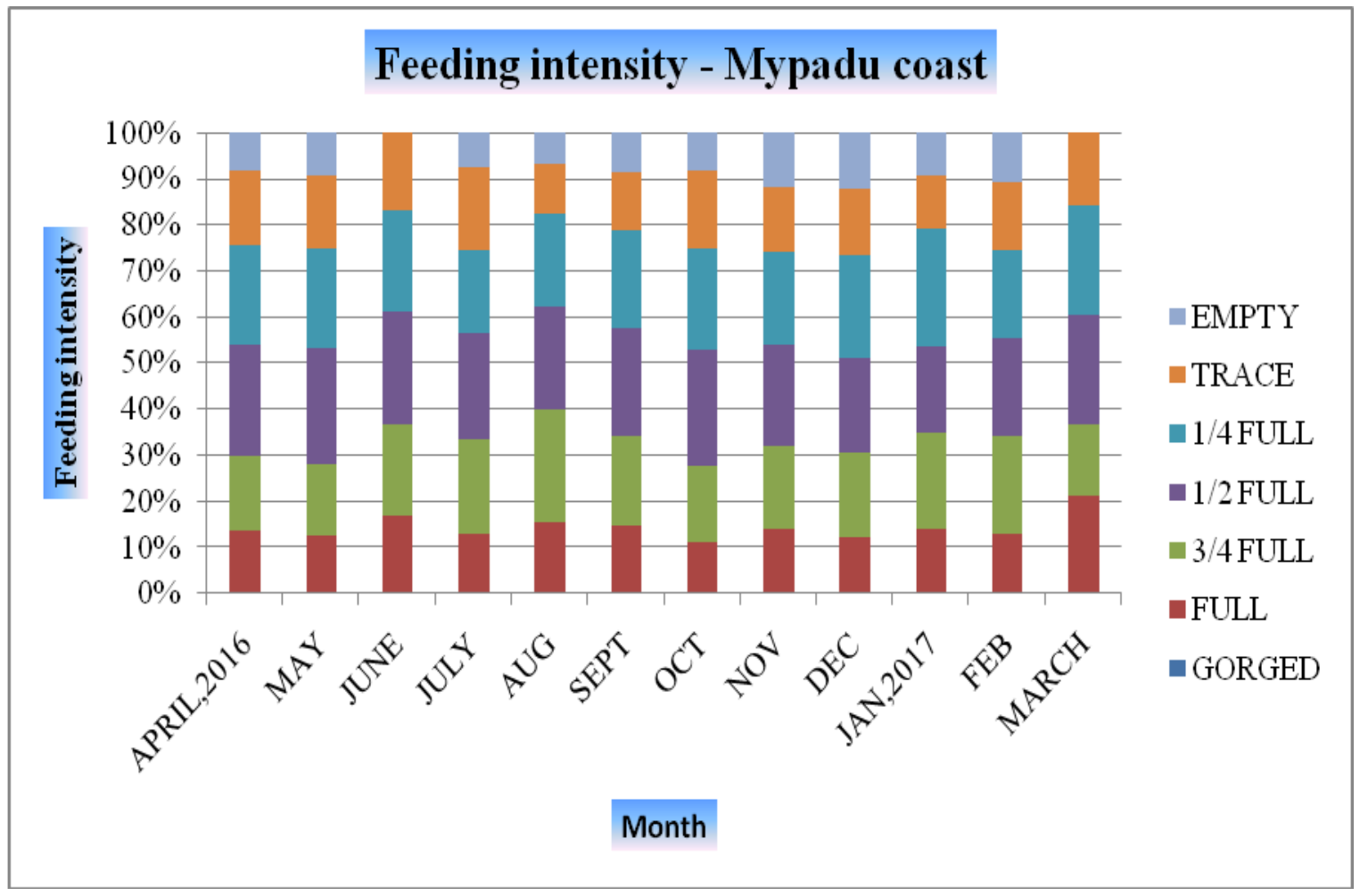


Fig.5 Month-wise percentage of GaSI of M. cephalus from Kp coast

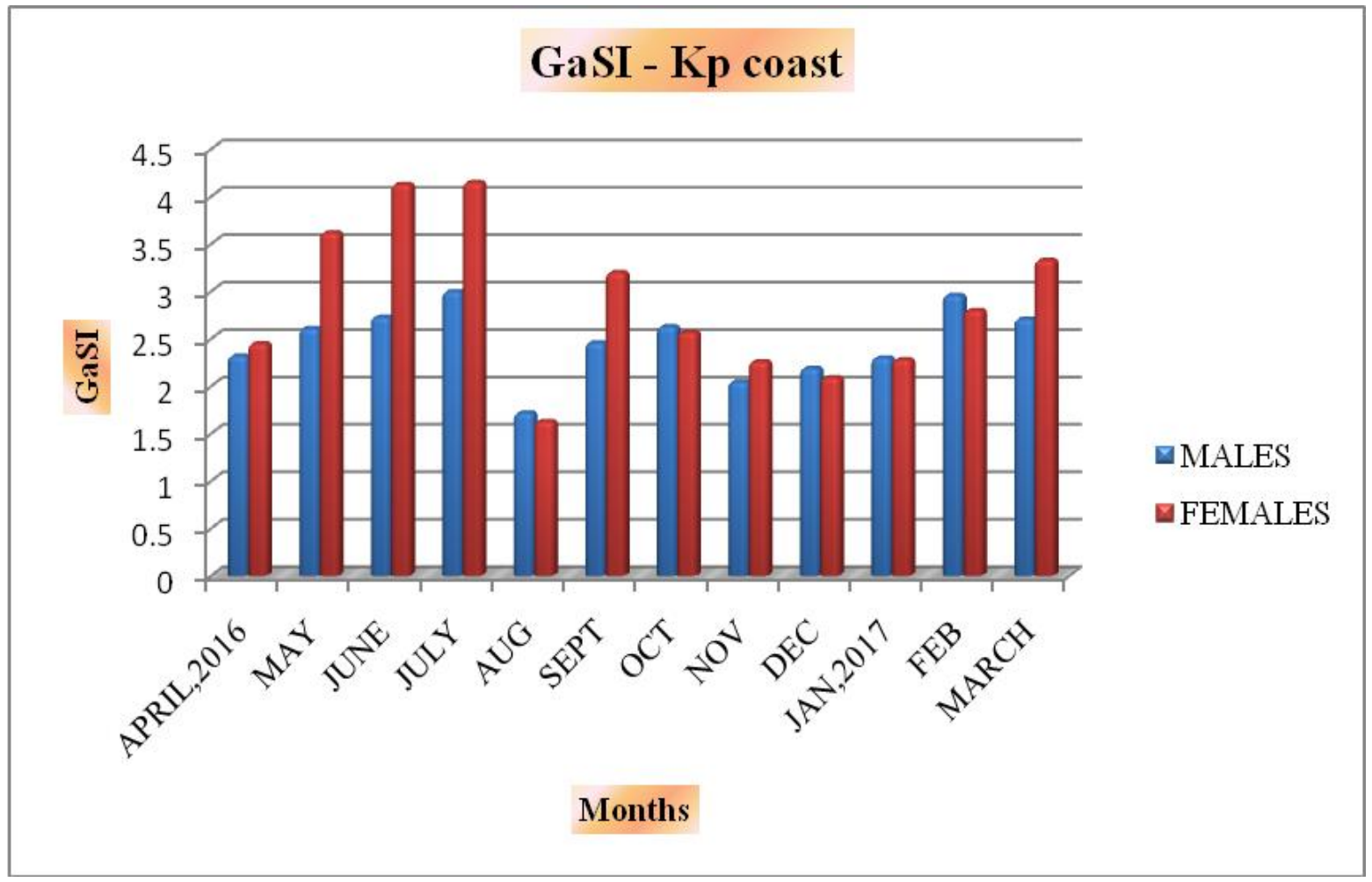

Fig.6 Month-wise percentage of GaSI of M. cephalus from Mypadu coast

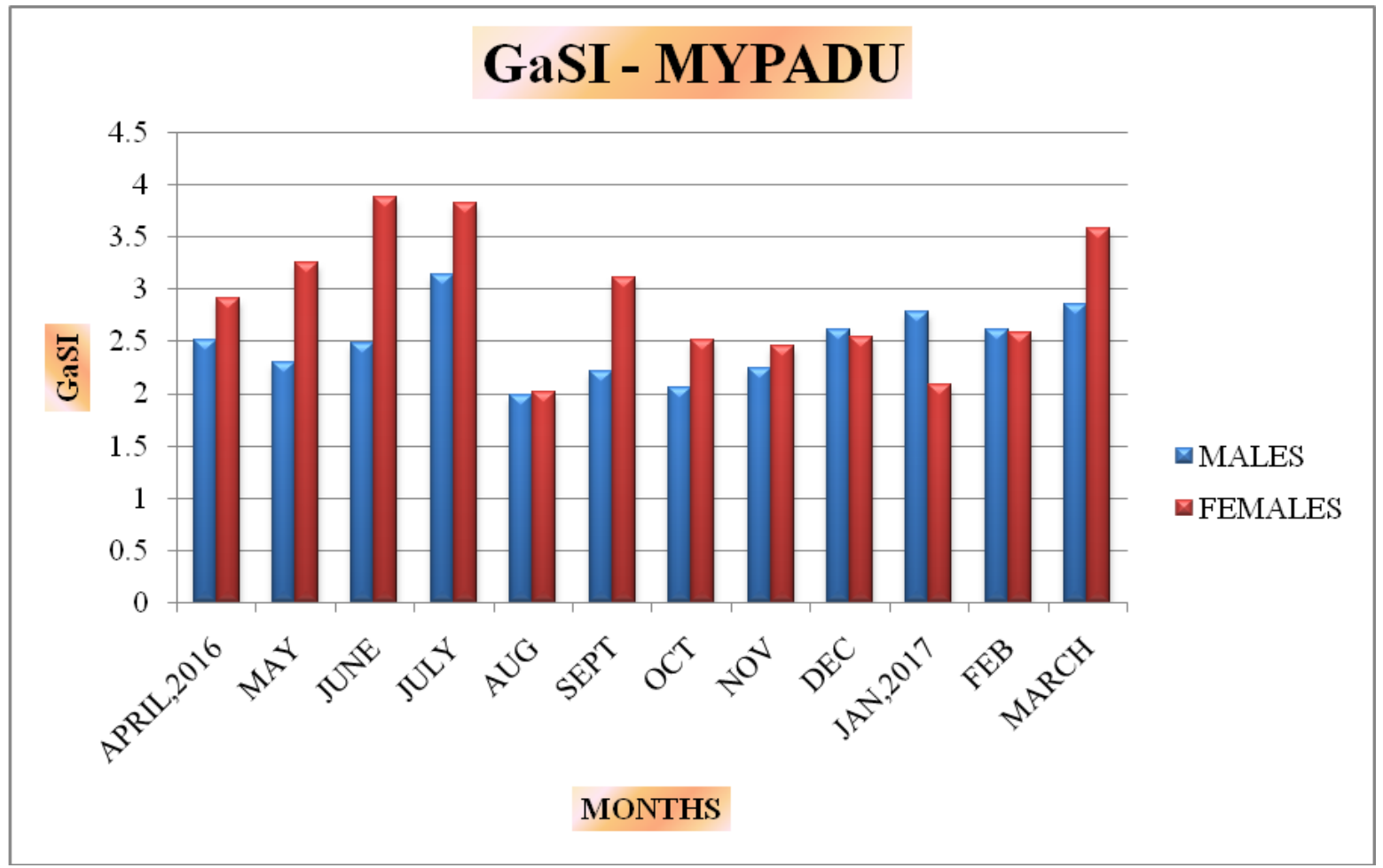


Plate.1 Anatomical view of alimentary canal of M.cephalus

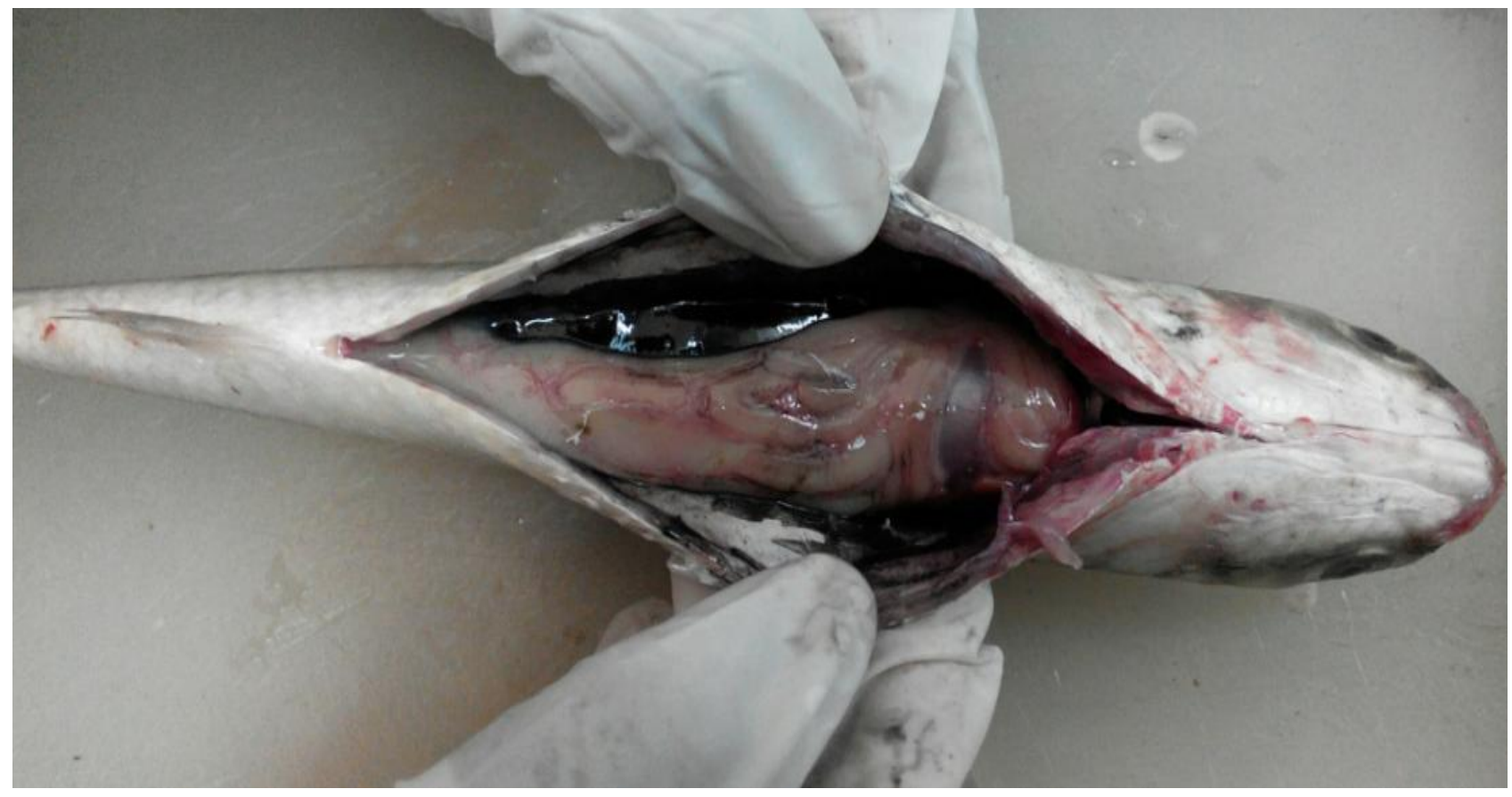

Plate.2 Alimentary canal of M.cephalus

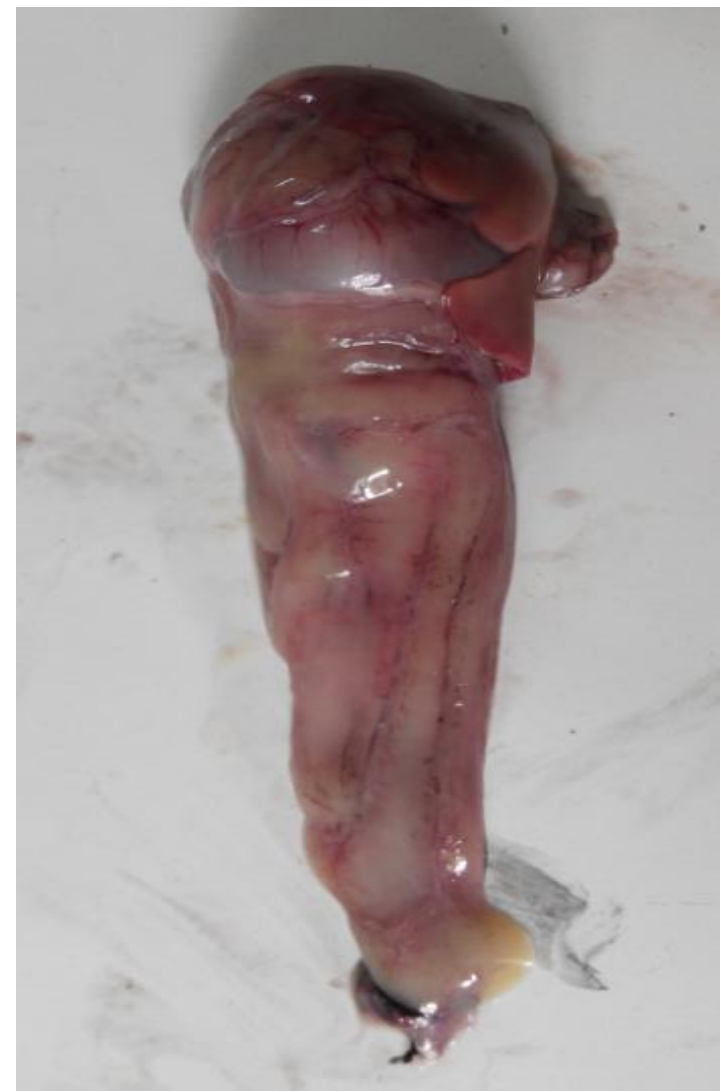


Plate.3 (Gizzard) Stomach of M.cephalus

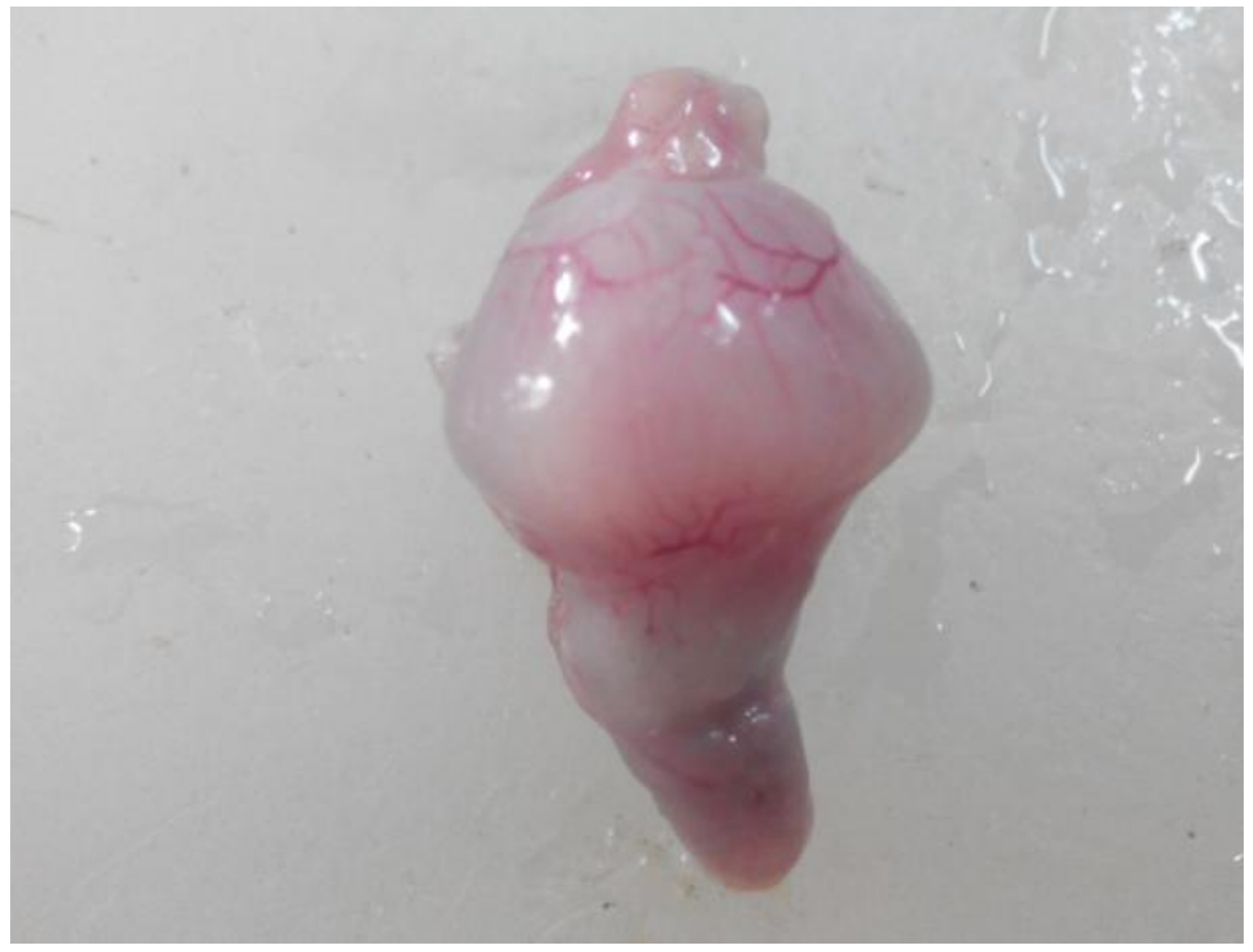

Plate.4 Microscopic observation of gut contents (A gastropod shell)

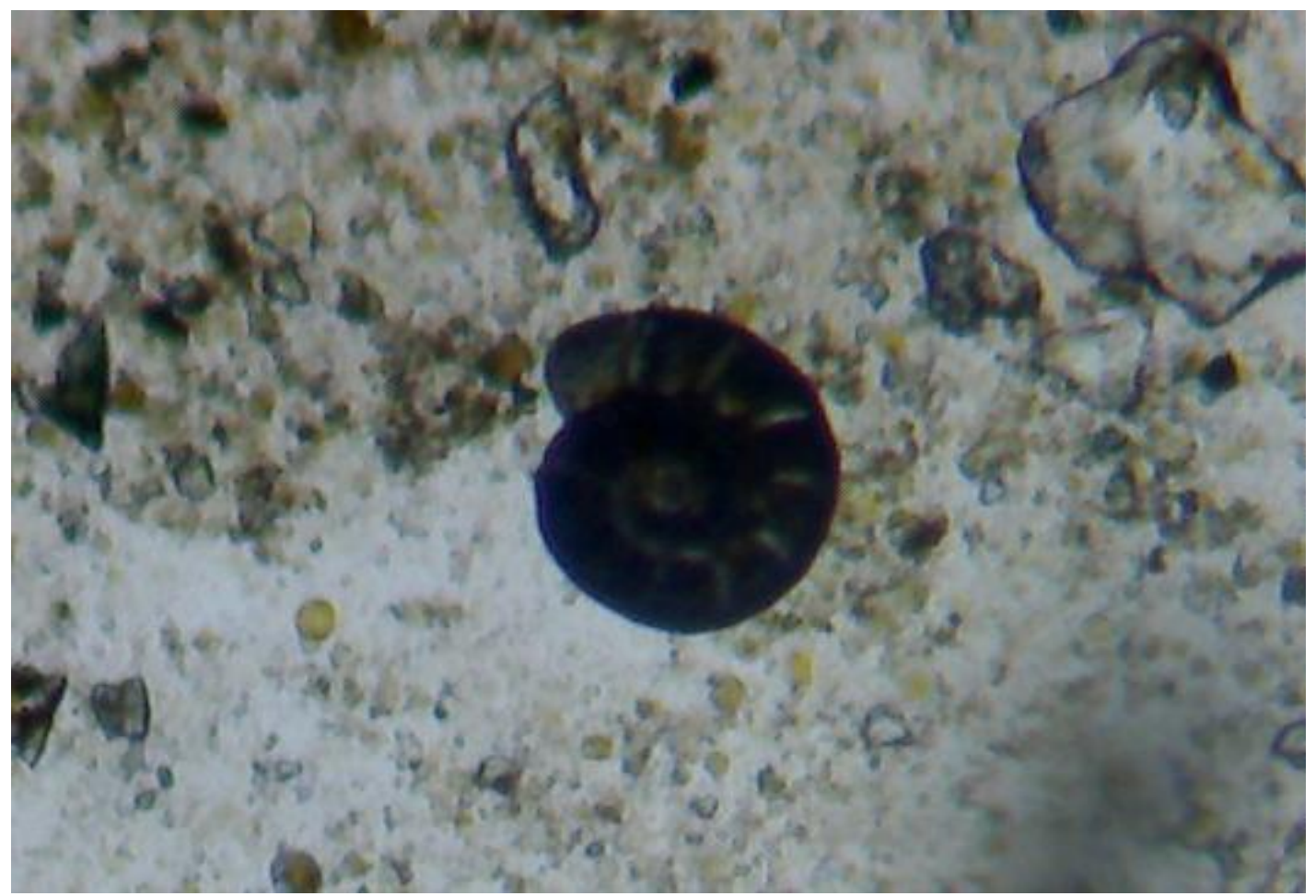


Plate.5 Microscopic observation of gut contents (Fish scale)

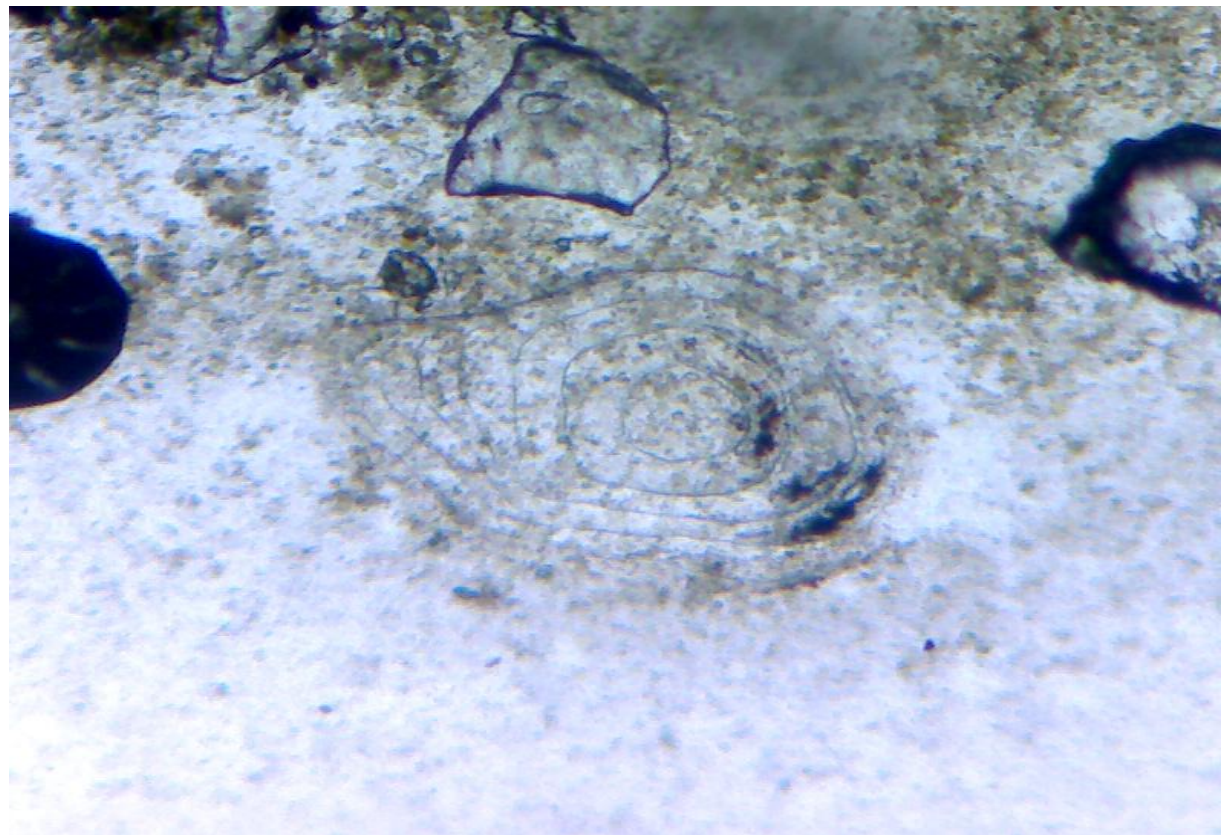

Plate.6 Microscopic observation of gut contents (bivalve spat and gastropods)

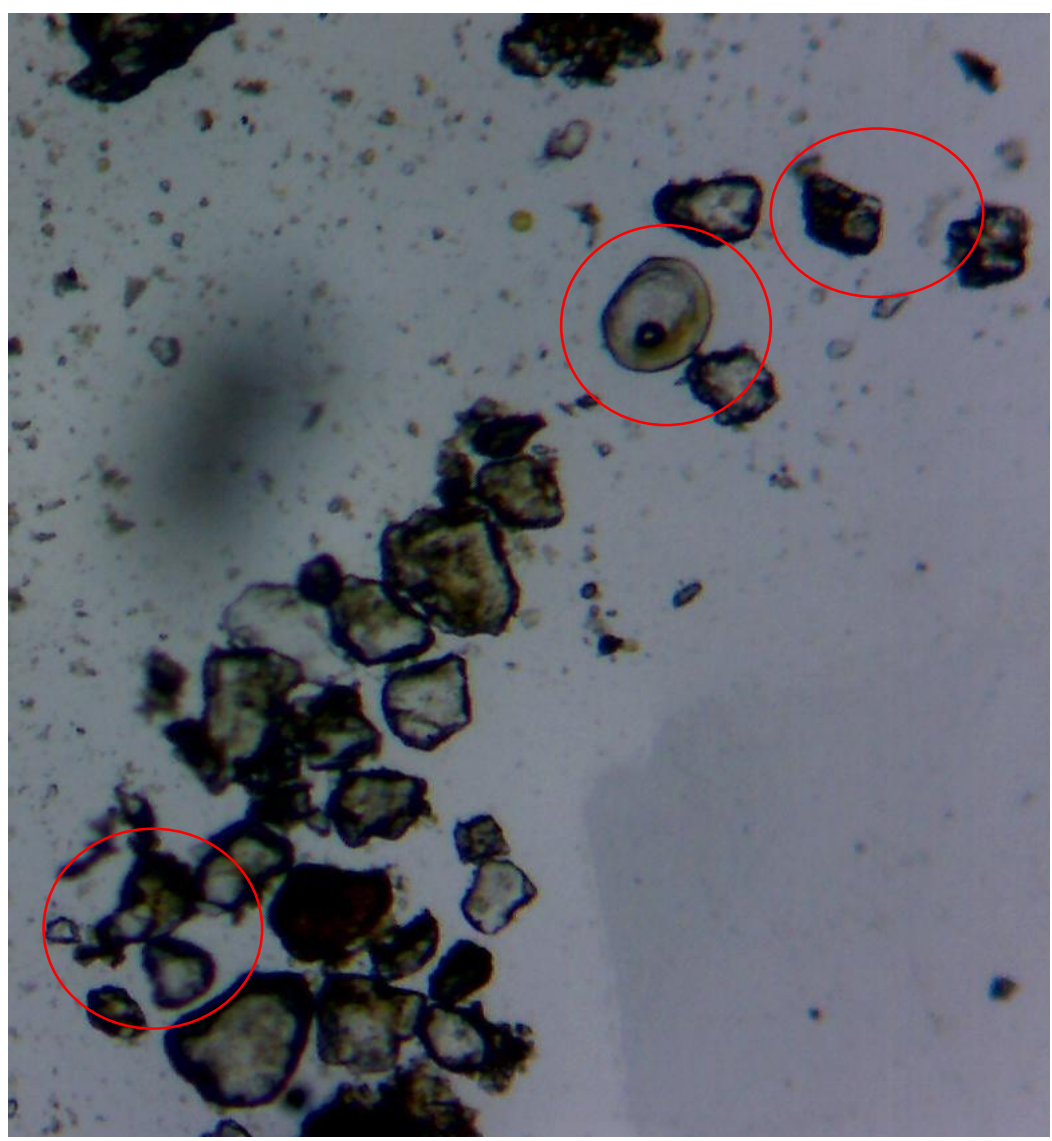


In case of female, the highest GaSI value were found in the month of July (4.15) followed by June (4.13) and May (3.62) and the lowest values were found during August (1.56) followed by December (2.09) and November (2.26).

\section{Month-wise GaSI of $M$. cephalus from Mypadu coast}

The values of GaSI (male and Female) are presented in Table 6. In males, highest GaSI values were estimated for the month of July, 2016 (3.14) followed by March, 2017 (2.86) and January, 2017 (2.78) and lowest were estimated during August (1.99) followed by October (2.06). In case of female, the highest GaSI values were found in the month of June (3.89) followed by July (3.82) and the lowest values were found during August (2.02) followed by January, 2017 (2.09) (Fig. 6).

\section{Food items}

Mullets are primarily benthic feeders. The presence of large quantities of the dead and decaying organic matter settled at the bottom layers of the habitat and algae consisting of Bacillariophyceae, Chlorophyceae and Myxophyceae along with other benthic organisms in the guts of adults, they were considered as benthic feeders by earlier workers (Egusa, 1950; Yashouv and Ben Schacher, 1970; De Silva and Wijeyaratyne, 1977). In the present investigation, $M$. cephalus is found to be omnivorous feeding habit from both $\mathrm{Kp}$ and Mypadu coasts feeding mainly on diatoms, algal matter, macrophytes, molluscs, detritus, sand and mud, fish scales, eggs and insects. $M$. cephalus fed majorly on diatoms (34.178\%), sand and mud $(32.52 \%)$, decayed organic matter (O.M.) (20.035\%) and algal matter $(10.238 \%)$ from $\mathrm{Kp}$ coast. Various items majorly comprised in the diet of $M$. cephalus from Mypadu coast are sand and mud
$(37.953 \%)$, diatoms $(30.817 \%)$, decayed organic matter $(19.059 \%)$ and algal matter $(9.466 \%)$. Earlier studies indicated that the diet of young mullets consisted predominantly on the diatoms (Bachllariophyceae) followed by the green algae and blue-green algae (De Silva and Wijeyaratyne, 1977; Wells, 1984; Sanchez Rueda, 2002). In the present study Diatoms were the major food item of $M$. cephalus from both $\mathrm{Kp}(34.178 \%)$ and Mypadu coasts (30.817\%).

Mullets generally feed by grazing on submerged rock and plant surface and the function of inorganic particles of the diet is suggested in the grinding activity to degrade plant cell walls in the pyloric portion (Thomson, 1966; Blaber, 1976). Sand and mud comprised the major portion in the gut contents (35.52\% from Kp and 37.953\% from Mypadu coasts) of the fishes. Similar results were obtained by Kurma Rao and Ramesh Babu (2013) in the study of $M$. cephalus from East Coast of India. They observed the gut contents of juveniles and adults consist of $30 \%$ of sand, silt and mud. Quantitative estimations by Anila Kumary (2015) from Kayamkulam estuary showed that diatoms are the most abundant among the total gut contents contributing to about $58.44 \%$ followed by decayed organic matter $(15.02 \%)$ and sand and mud (6.69\%). Wells (1984) noticed the $M$. cephalus ingested a number of gastropods in River Waikato and Lake Waahi. However, in the present study gastropods were ingested in lesser quantities.

\section{Feeding intensity}

Analysis of degrees of fullness of stomach indicated maximum percent of fishes were found as moderately fed. Moderately fed stomachs were encountered low during December, 2016 (15.55\%) from Kp coast. Maximum percent of moderately fed stomachs were encountered during August, 
2016 (46.66\%) followed by July, 2016 $(43.59 \%)$ and empty stomachs in the month of December, 2016 (12.24\%) from Mypadu coast. From both the coasts fishes were found relatively low fed in the month of December, 2016. Maximum percent of fishes with full stomachs were encountered in the month of May, 2016 (19.35\%) and April, 2016 $(18.75 \%)$ from Kp coast; March, 2017 (21.06\%) and June, 2016 (17.07\%) from Mypadu coast. Kurma Rao and Ramesh Babu (2013) observed the guts were maximum in the months of October, 2010 followed by August, 2011 and September, 2010 and the volumes of gut contents were also relatively higher in the months of February, 2011 and March, 2011 shown that there were two peaks in a year i.e., one during February, 2011 and March, 2011 and another during August to October period. No regular pattern was observed in the intensity of feeding by Anila Kumary (2015) from Kayamkulam estuary. She observed an increase in the proportion of actively fed fishes from September, 2010 with its maximum during October, 2010. Monsoon season is characterized by the maximum number of poorly fed fishes $(74.63 \%)$ while the maximum of actively fed fishes $(28.21 \%)$ were during the post monsoon period. Tandel et al., (1986) concluded that August, 1981 to December, 1981 can be attributed to the low feeding intensity in $M$. cephalus from Thana creek which was similar to the present study. A.R. Joadder and Hossain (2008) found the highest percent of emptiness of stomachs in November $(1998,1999)$ for Liza parsia from Bangladesh.

\section{Gastro-somatic index (GaSI)}

The values of gastro-somatic index in the present study ranged from 1.56 to 4.15 (males - 1.72 to 3.08; females - 1.56 to 4.15 ) from Kp coast and 1.99 to 3.89 (males - 1.99 to 3.14; females - 2.02 to 3.89) from Mypadu coast. Values of gastro-somatic index showed higher feeding intensity during July, 2016 (3.08) and February, 2017 (2.96) while lower feeding intensity was observed during August, 2016 (1.72) and November, 2016 (2.05) for males and in females higher feeding intensity was observed during July, 2016 (4.15) and June, 2016 (4.13) with the lower feeding intensity in August, 2016 (1.56) from Kp coast. Whereas in Mypadu coast, highest GaSI encountered for males in July, 2016 (3.14) and March, 2017 (2.86) and lowest in August, 2016 (1.99) followed by October, 2016 (2.06). In females highest GSI found in June, 2016 (3.89) and July, 2016 (3.82) and lowest in August, 2016 (2.02). In a study by D.S. Pramanik and S.S. Mohanty (2016), GaSI\% in M. cephalus was observed to be 5.904 in summer, 4.957 in winter, 6.600 in monsoon and 6.526 in post monsoon which are higher than the present study. In their study lower value was observed in winter. But in present study, low GaSI values were observed during monsoon season. This may be due to the disturbance of benthic ecosystem due to rainfall and inflow of freshwaters.

\section{References}

Anila Kumary, K.S., 2015. Food and feeding habits of Mugil cephalus of Kayamkulam estuary, Kerala. International Journal of Aquaculture. 5 (6): 1-3.

Blaber, S.J.M., 1976. The food and feeding ecology of Mugilidae in the St. Lucia lake system. Biol. J. Linn. Soc. 8: 267277.

De Silva, S.S. and Wijeyaratne, M.J.S., 1977. Studies on the biology of young grey mullet, Mugil cephalus L. II. Food and Feeding. Aquaculture. 12 (2): 157-167.

Egusa, S., 1950. Some notes on the feeding habit of the young of Mugil cephalus L. Bull. Jap. Soc. Sci. Fish. 5 (11): 715720. 
International Centre for Living Aquatic Resources Management (ICLARM), 1980. Introduction. In Review of breeding and propagation techniques for grey mullet, Mugil cephalus L. (C.E. Nash and Z.H. Shehadeh, ed.). ICLARM Studies and Reviews, pp. 3: 87.

Joadder, A.R. and Hossain, M.D., 2008. Convenient pattern of food and feeding habit of Liza parsia (Hamilton) (Mugiliformies: Mugilidae). Journal of Fisheries International. 3 (3): 61-64.

Koutrakis, E.T., Sinis A.I. and Economidis P.S., 1994. Seasonal occurrence, abundance and size distribution of grey mullet fry (Pisces: Mugilidae) in the Porto-Lagos lagoon and Lake Vistonis (Aegaean Sea, Greece). Bamidgeh. 46 (4): 182-196.

Kurma Rao and Ramesh Babu, 2013. Studies on food and feeding habits of Mugil Cephalus (Linnaeus, 1758) East Coast off Andhra Pradesh, India. SENRA Academic Publishers, British Columbia. 7 (3): 2499-2504.

Nair, K. V. S., 1980. Food and feeding habits of Johnieops sina (Cuvier). Indian J. Fish. 27 (1 \& 2): 24-34.

Pramanik, D.S. and Mohanty, S.S., 2016. Length-weight relationship and biology of some common edible fish species at Chandipur, Bay of Bengal, Odisha.
International Journal of Fisheries and Aquatic Studies. 4 (1): 335-340.

Sanchez Rueda, P., 2002. Stomach content analysis of Mugil cephalus and Mugil curema (Mugiliformes: Mugillidae) with emphasis an diatoms in the Tamiahua Lagoon, Mexico. Revista Biologia Tropical. 50 (1): 245-252.

Tandel, S.S., Athalye, R.P. and Gokhale, K.S., 1986. On the seasonal changes in food habit of Mugil cephalus of the Thana creek. Indian Journal of Fisheries. 33 (3): 270-276.

Thomson, J.M., 1966. The grey mullets. Oceanogr. Mar. Biol. Ann. Rev. 4: 301355.

Wells, R.D.S., 1984. The food of the grey mullet (Mugil cephalus L.) in Lake Waahi and the Waikato river at Huntly. New Zealand Journal of Marine and Freshwater Research. 18: 13-19.

Wijeyaratne, M. J. S. and Costa, H. H., 1986. On the biology of an estuarine population of grey mullet, Mugil cephalus L. in Negambo lagoon, Sri Lanka. Cybium. 10: 351-363.

Yashouv, A. and Ben-Shachar, A., 1970. Breeding and growth of Mugilidae II. Feeding experiments under laboratory conditions with Mugil cephalus L. and Mugil capito Cuvier. Bamidgeh. 19: 5066.

\section{How to cite this article:}

Lavanya, D., D. Ramalingaiah, T. Suguna, D. Raveendra Kumar Reddy and Madhavi, K. 2018. Food and Feeding Ecology of Mugil cephalus from Krishnapatnam and Mypadu Coasts of Nellore District, Andhra Pradesh, India. Int.J.Curr.Microbiol.App.Sci. 7(04): 2616-2630. doi: https://doi.org/10.20546/ijcmas.2018.704.298 